\title{
Penerapan Akad Murabahah pada Produk MULIA di Pegadaian Jalancagak Menurut Perspektif Ekonomi Syariah
}

\author{
R. Andriana Meirani ${ }^{1}$, Ahmad Damiri $^{2}$, Jalaludin ${ }^{3}$ \\ ${ }^{1}$ STAI Riyadhul Jannah Subang \\ ${ }^{2}$ UIN Sunan Gunung DJati Bandung \\ ${ }^{3}$ STIE Syariah Indonesia Purwakarta \\ ${ }^{1}$ anagalih98@gmail.com \\ 2ahmad.damiri86@gmail.com \\ Jalaludinstiesip@gmail.com
}

\begin{abstract}
Abstrak-Penelitian ini dilaksanakan di Pegadaian Jalancagak Kabupaten Subang. Pegadaian adalah salah satu lembaga keuangan yang menawarkan jasa investasi Logam Mulia yang salah satu produknya dinamakan MULIA (Murabahah Logam Mulia Untuk investasi Abadi). Produk Mulia merupakan penawaran pembiayaan kepada nasabah untuk pembelian Emas batang yang di produksi oleh PT. Aneka Tambang (ANTAM). Penelitian ini bertujuan untuk mengetahui bagaimana ketentuan produk MULIA, penerapan akad Murabahah pada produk MULIA serta dampak produk MULIA bagi pegadaian dan masyarakat. Jenis penelitian ini adalah kualitatif dengan menggunakan metode deskriptif analisis. Sumber data yang digunakan meliputi data primer dan sekunder. Dari hasil pembahasan peneliti mendapatkan ada beberapa ketentuan dalam penerapan akad Murabahah produk MULIA di Pegadaian Jalancagak yang belum sesuai dengan ketentuan syariat, diantaranya; pertama mengenai Objek akad atau Marhun yang tidak dimunculkan atau tidak ada ketika akad berlangsung. Kedua, mengenai sanksi yang dibolehkan menurut syariat adalah berlaku untuk nasabah yang mampu tapi lalai atau menunda nunda pembayaran tapi tidak berlaku untuk nasabah yang benar-benar tidak mampu membayar, namun dalam penerapannya di pegadaian Jalancagak mengharuskan semua nasabah menerima sanksi atau membayar denda apabila tidak mampu membayar tanpa kecuali. Ketiga, dalam penerapan sanksi/denda mengenai dana yang dihasilkan dari denda di masukan sebagai pendapatan Perusahaan, yang secara ketentuan syariat seharusnya diperuntukan untuk dana sosial

Kata kunci: Murabahah, Produk MULIA
\end{abstract}

Abstract-This research was conducted at Pegadaian Jalancagak Subang Regency. Pegadaian is one of the financial institutions that offers Logam Mulia investment services, one of which is called MULIA (Murabahah Logam Mulia For Abadi Investment). Product Mulia is a financing offer to customers for the purchase of gold bars produced by PT. Aneka Tambang (ANTAM). This study aims to determine how MULIA product provisions, the application of the murabaha contract on MULIA products and the impact of MULIA products for pawnshops and the community. This type of research is qualitative using descriptive analysis method. Data sources used include primary and secondary data. From the results of the discussion the researchers found that there were several provisions in the application of the MULIA product Murabahah in Pegadaian Jalancagak that were not in accordance with the provisions of the Shari'a, including; first concerning the object of the contract or Marhun which was not raised or did not exist during the contract. Second, the sanctions that are permitted according to the Shari'a are applicable to customers who are capable but neglect or postpone delay of payment but do not apply to customers who are truly unable to pay, but in its application at Jalancagak pawnshop requires all customers to receive sanctions or pay fines if unable pay without exception. Third, in the application of sanctions / fines regarding funds generated from fines input as corporate income, which according to Shari'a provisions should be intended for social funds

Keywords: Murabaha, MULIA Product

R. Andriana Meirani | Penerapan Akad Murabahah pada ...... | 60 


\section{PENDAHULUAN}

Pegadaian mempunyai sebuah produk investasi emas logam mulia yang bernama MULIA (Murabahah Logam Mulia untuk Investasi Abadi). Produk MULIA merupakan penawaran pembiayaan kepada nasabah untuk pembelian Emas batang yang di produksi oleh PT Aneka Tambang (ANTAM) yang dapat dilakukan secara tunai maupun angsuran dengan jangka waktu bervariasi. Produk MULIA di pegadaian (Persero) telah diluncurkan sejak tahun 2008 dan pada awalnya diluncurkan khusus hanya dapat dilayani oleh unit pelayanan Cabang Syariah, dan sejak tahun 2010 telah diluncurkan untuk dapat dilayani oleh Unit Pelayanan Cabang Konvensional (Tanuwidjaja, 2009).

Pembiayaan Murabahah adalah transaksi jual beli dimana Bank atau lembaga keuangan bertindak sebagai penjual dan nasabah sebagai pembeli, yang mana dalam hal ini Pegadaian sebagai pihak pertama menjual barang kepada pihak kedua sebesar harga pokok ditambah dengan margin/ keuntungan berdasarkan kesepakatan bersama antara kedua belah pihak yang berakad. Pembiayaan Murabahah pada produk MULIA di pegadaian ada dua cara yaitu, pembayaran tunai dan pembayaran angsuran. Apabila pembayaran angsuran maka nasabah harus menyetujui dan memberikan emasnya untuk dijadikan jaminan pelunasan hutang oleh pegadaian. Pada sistem pembayaran angsuran (Afrida, 2016).

Persyaratan Murabahah diantaranya, Bank dan nasabah harus mengadakan akad Murabahah yang bebas riba, barang yang diperjual-belikan tidak termasuk kategori yang diharamkan oleh syariat islam. Bank harus menyampaikan semua hal yang berkaitan dengan pembelian, misalnya jika pembelian dilakukan secara hutang, bank kemudian menjual barang tersebut kepada nasabah (pemesan) dengan harga jual senilai harga perolehan ditambah keuntungannya. Nasabah membayar harga yang disepakati sesuai jangka waktu yang disepakati. Bank dapat mencegah terjadinya penyalahgunaan atau kerusakan akad melalui perjanjian tambahan dengan nasabah. Jika hendak mewakilkan kepada nasabah untuk membeli barang dari pihak ketiga, akad jual beli Murabahah harus dilakukan setelah barang secara prinsip menjadi milik bank. Jika bank menerima permintaan nasabah akan suatu barang atau aset, ia harus membeli terlebih dahulu aset yang dipesan tersebut dan bank harus menyempurnakan jual beli yang sah dengan pedagang tersebut (Maruta, 2016).

Penelitian ini bertujuan untuk: pertama untuk mengetahui ketentuan produk MULIA di Pegadaian Jalancagak, kedua untuk mengetahui penerapan akad Murabahah pada produk MULIA di Pegadaian Jalancagak, ketiga untuk mengetahui dampak bagi masyarakat dan lembaga terhadap produk MULIA di Pegadaian Jalancagak.

Murabahah atau disebut juga ba'bitsmanil ajil. Kata Murabahah berasal dari kata ribhu (keuntungan). Sehingga Murabahah berarti saling menguntungkan. Dalam Murabahah penjual harus memberitahu harga produk yang di beli dan menentukan suatu tingkat keuntungan sebagai tambahannya (Mardani, 2015).

Jual beli menurut bahasa berarti al- 'Bai', alTijarah dan al-Mubadalah.Yaitu suatu perjanjian tukar-menukar benda atau barang yang mempunyai nilai secara sukarela di antara kedua belah pihak, yang satu menerima benda-benda dan pihak lain menerimanya sesuai dengan perjanjian atau ketentuan yang telah dibenarkan Syara' dan disepakati (Suhendi, 2010).

Beberapa dalil dalam Al-Quran dan AlHadits yang menjelaskan tentang transaksi jualbeli Murabahah :

a. Firman Allah QS. An-Nisa ayat 29

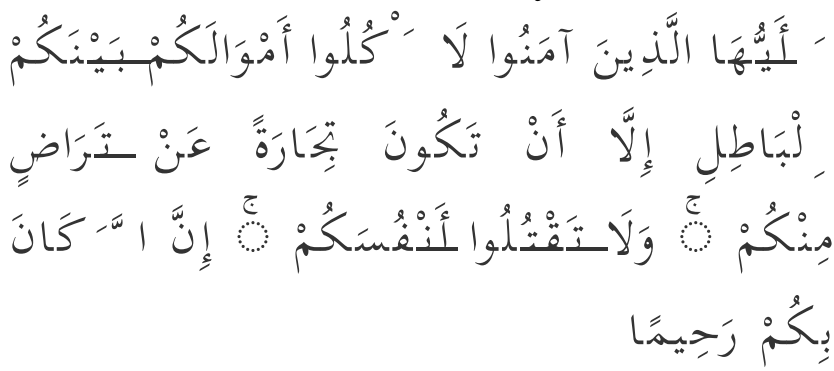

"Hai orang-orang yang beriman, janganlah kamu saling memakan harta sesamamu dengan jalan yang batil, kecuali dengan jalan perniagaan yang berlaku dengan suka sama-suka di antara kamu. Dan janganlah kamu membunuh dirimu; sesungguhnya Allah adalah Maha Penyayang kepadamu” (Enang, 2010). 


\section{EKSISBANK Vol. 4 No. 1 Juni 2020}

HR. Al-Baihaqi dan Ibnu Majah dari Abu Sa'id al-Khudri bahwa Rasulullah SAW bersabda:

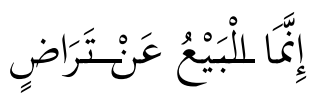

"Sesungguhnya jual beli itu hanya boleh dilakukan atas dasar kerelaan (antara kedua belah pihak)."

Rukun dalam Murabahah terdiri dari : Bai' (penjual), Musytari (pembeli), Mabi' (barang yang diperjual-belikan), Tsaman (harga barang), Ijab-qabul (pernyataan serah terima). Sedangkan syarat Murabahah terdiri dari 4 poin, pertama Pihak yang berakad (Bai' \& Musytari) cakap hukum dan tidak dalam keadaan terpaksa, kedua barang yang diperjual-belikan (Mabi') tidak termasuk barang haram dan jenis maupun jumlahnya jelas, ketiga harga barang (Tsaman) harus dinyatakan secara transparan (harga pokok dan komponen keuangan) dan cara pembayarannya disebutkan dengan jelas, keempat pernyataan serah terima (Ijab-Qabul) harus jelas dengan menyebutkan secara spesifik ke pihakpihak yang berakad serta akadnya dinyatakan secara tertulis (Ismail, 2015).

Menurut bahasa, gadai (Al-rahn) berarti altsubut dan al-habs yaitu penetapan dan penahanan. Ada pula yang menjelaskan bahwa rahn adalah terkurung atau terjerat (Suhendi, 2010). Sedangkan menurut istilah, al-rahnadalah menahan salah satu harta milik si peminjam sebagai jaminan atas pinjaman yang diterimanya. Barang yang ditahan tersebut memiliki nilai ekonomis. Dengan demikian, pihak yang menahan memperoleh jaminan untuk dapat mengambil kembali seluruh atau sebagian piutangnya (Antonio, 2001). Akad rahn bertujuan agar pemberi pinjaman lebih mempercayai pihak yang berhutang. Dengan kata sederhana, gadai merupakan jaminan dari peminjam kepada pemberi utang (Sri, 2009).

Dasar Hukum Gadai (Ar-Rahn) yang pertama dari Al-Qur'an surat Al-Baqarah ayat 283:

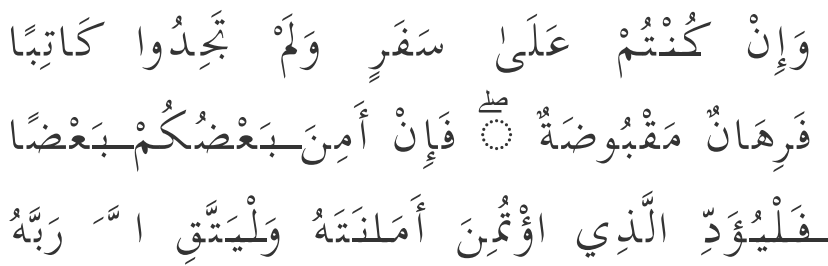

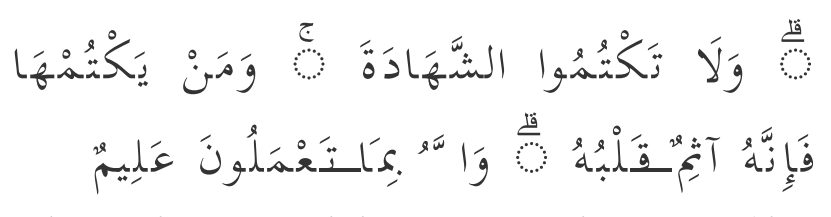

"Jika kamu dalam perjalanan (dan bermu'amalah tidak secara tunai) sedang kamu tidak memperoleh seorang penulis, maka hendaklah ada barang tanggungan yang dipegang (oleh yang berpiutang). Akan tetapi jika sebagian kamu mempercayai sebagian yang lain, maka hendaklah yang dipercayai itu menunaikan amanatnya (hutangnya) dan hendaklah ia bertakwa kepada Allah Tuhannya; dan Dan janganlah kamu (para saksi) menyembunyikan persaksian. Barang siapa yang menyembunyikannya, maka sesungguhnya ia adalah orang yang berdosa hatinya; dan Allah Maha Mengetahui apa yang kamu kerjakan...." (Enang, 2010).

Kedua Al- Hadits

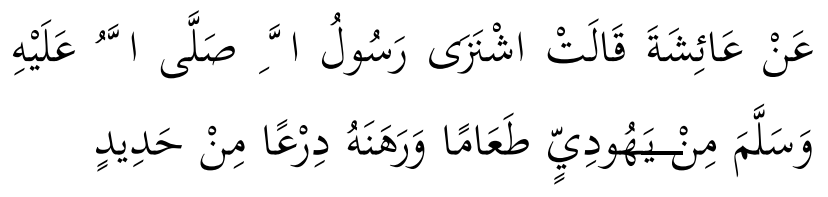

"Rasulullah saw. pernah membeli makanan dari seorang Yahudi dengan cara menangguhkan pembayarannya, lalu beliau menyerahkan baju besi beliau sebagai jaminan". (shahih muslim)" (Enang, 2010).

Ketiga dari Ijma' Ulama, Jumhur ulama menyepakati kebolehan status hukum gadai. Hal ini dimaksud, berdasarkan pada kisah Nabi Muhammad SAW yang menggadaikan baju besi kepada seorang Yahudi. Para ulama juga menggambil indikasi dari contoh Nabi Muhammad SAW (Lubis, 2000).

MULIA adalah salah satu produk investasi di Pegadaian yang ditawarkan kepada masyarakat dengan sistem syariah dengan menggunakan akad Murabahah dan Rahn. Kata MULIA mempunyai arti tersendiri yakni (Murabahah Logam Mulia Untuk Investasi Abadi) (Harpen, 2015) . MULIA adalah layanan penjualan Emas batangan kepada masyarakat secara tunai atau angsuran dengan proses mudah dan jangka waktu yang fleksibel. MULIA dapat menjadi alternatif pilihan investasi yang aman untuk mewujudkan masa depan, seperti menunaikan ibadah Haji, mempersiapkan biaya pendidikan anak, memiliki rumah idaman serta kendaraan pribadi yang menjadi idaman para nasabah yang akan melakukan atau menjadi 
anggota dari pegadaian melakukan pembiayaan cicil emas (Taufik Diya et al., 2012).

Ketentuan Murabahah kepada nasabah (menurut fatwa DSN No:04/DSN-MUI/V/2000):

1. Nasabah melakukan permohonan dan janji pembelian suatu barang atau aset kepada bank.

2. Jika bank menerima permohonan tersebut, Ia harus membeli terlebih dahulu aset yang dipesannya secara sah dengan pedagang.

3. Bank kemudian menawarkan aset tersebut kepada nasabah dan nasabah harus menerima (membeli)-nya sesuai dengan janji yang telah disepakatinya, karena secara hukum janji tersebut mengikat, kemudian kedua belah pihak harus membuat kontrak jual beli.

4. Dalam jual beli ini bank dibolehkan meminta nasabah untuk membayar uang muka saat menandatangani kesepakatan awal pemesanan.

5. Jika nasabah kemudian menolak membeli barang tersebut, biaya riil bank harus dibayar dari uang muka tersebut.

6. Jika uang muka kurang dari kerugian yang harus ditanggung oleh Bank, Bank dapat meminta kembali sisa kerugian kepada nasabah.

Jaminan dalam Murabahah (menurut fatwa DSN No:04/DSN-MUI/V/2000):

1. Jaminan dalam Murabahah diperbolehkan, agar nasabah serius dengan pesanan nya.

2. Bank dapat meminta nasabah untuk menyediakan jaminan yang dapat dipegang (RAHN EMAS, 2002; RAHN, 2002).

\section{METODOLOGI PENELITIAN}

Metode yang digunakan dalam penelitian ini adalah metode kualitatif. Dengan menggunakan metode ini, peneliti dapat memaparkan (mendeskripsikan) maupun memberikan gambaran suatu satuan analisis secara utuh yang terintegritas. Dalam metode ini satuan analisis yang dimaksud berupa satuan penellitian yang dilakukan secara intensif, terinci dan mendalam terhadap suatu organisasi, lembaga (Arikunto, 2016).

Berdasarkan pada materi penulis akan megumpulkan, mengelola, mengklarifikasi, menganalisis data dan melaporkan hasil penelitian objektif sesuai dengan hasil penelitian lapangan berupa observasi dan wawancara dengan responden atau pihak pihak yang terlibat dalam penelitian ini diantaranya pihak lembaga dan nasabah, juga referensi dari berbagai sumber bacaan.

\section{HASIL DAN PEMBAHASAN \\ A. Ketentuan Produk MULIA di Pegadaian Jalancagak}

1. Syarat Menjadi Konsumen/Nasabah

Syarat menjadi nasabah di pegadaian diantaranya, harus mempunyai kartu identitas diri seperti KTP, kemudian KK (Kartu Keluarga) kemudian menyerahkan agunan atau jaminan apabila ingin melakukan gadai (Rahn).

2. Syarat permohonan pembiayaan MULIA

Pertama yang harus di lakukan adalah menyiapkan kelengkapan administrasi meliputi kartu identitas seperti KTP, Kartu Keluarga, kemampuan membayar uang muka, kemampuan membayar angsuran mulia, kemudian mengisi formulir pengajuan. Kemudian pengelola unit/cabang akan melakukan verifiksi data yang diberikan oleh nasabah.

\section{Prosedur pemberian mulia}

Prosedur pemberian Mulia yang dilakukan antara pihak pegadaian kepada nasabah terdiri dari beberapa aspek penilaian, yaitu menentukan jumlah pembiayaan Mulia, jangka waktu, jumlah unit emas logam mulia dan jumlah angsurannya. Proses pemberian mulia terbagi dua, yaitu proses produk mulia tunai dan proses produk mulia kredit.

4. Sanksi/Denda

Sanksi diberlakukan apabila nasabah menunggak atau terlambat membayar angsuran. Besaran denda yang di tentukan pihak pegadaian adalah sebesar $0,13 \%$ per hari dari jumlah agsuran. Denda berlaku untuk semua nasabah yang telat membayar angsuran tanpa kecuali.

5. Prosedur Pelunasan Mulia

Dalam prosedur pelunasan pembiayaan mulia dapat dilakukan melalui pembiayaan secara angsuran (cicilan) setiap bulan sampai tanggal jatuh tempo atau dengan pelunasan sekaligus sebelum tanggal jatuh tempo. 


\section{EKSISBANK Vol. 4 No. 1 Juni 2020}

\section{B. Penerapan akad Murabahah pada produk MULIA di Pegadaian Jalancagak}

Berdasarkan Hasil wawancara dengan Ibu Ayu selaku Karyawan Pegadaian Syariah, Pertimbangan Pegadaian mengeluarkan produk yang memakai akad Murabahah dan rahn adalah karena jika Pegadaian tidak menggunakan dua akad dan hanya menggunakan satu akad saja yakni Murabahah (jual beli) yang objeknya emas itu berarti sama saja dengan produk pembiayaan Murabahah di Bank yang lain yang dikeluarkan Bank Syariah, oleh sebab itu Pegadaian mengikat objek emas dengan akad rahn untuk memberikan identitas kepada nasabah bahwa sedang menggunakan produk dari Pegadaian (Rahayu, 2019).

Selain itu berdasarkan hasil wawancara dengan beberapa nasabah produk Mulia pegadaian, diantaranya bernama Sdr. Shonny Shonjaya dalam pelaksanaan akad Murabahah di pegadaian, pihak pegadaian memberikan keleluasaan bagi para nasabah untuk bertanya halhal yang sekiranya kurang atau belum dipahami oleh calon nasabahnya

\section{Tabel 1.1}

Fatwa DSN-MUI Nomor 77 tentang Jual-Beli Emas Secara Tidak Tunai

\begin{tabular}{|l|l|c|c|}
\hline \multirow{2}{*}{ No } & \multicolumn{1}{|c|}{$\begin{array}{c}\text { Jual beli Emas } \\
\text { Secara tidak } \\
\text { tunai }\end{array}$} & \multicolumn{2}{|c|}{$\begin{array}{c}\text { Kesesuaian } \\
\text { Syariah }\end{array}$} \\
\cline { 2 - 4 } & $\begin{array}{l}\text { Yaal beli Emas } \\
\text { secara tidak tunai } \\
\text { hukumnya boleh, } \\
\text { selama emas tidak } \\
\text { jadi alat tukar } \\
\text { resmi (uang) }\end{array}$ & $\checkmark$ & Tidak \\
\hline 2 & $\begin{array}{l}\text { Harga jual tidak } \\
\text { boleh bertambah } \\
\text { selama jangka } \\
\text { waktu perjanjian } \\
\text { meskipun ada } \\
\text { perpanjangan } \\
\text { waktu setelah } \\
\text { jatuh tempo }\end{array}$ & $\checkmark$ & \\
\hline 3 & $\begin{array}{l}\text { Emas yang dbeli } \\
\text { dengan } \\
\text { pembayaran tidak } \\
\text { tunai boleh di } \\
\text { jadikan jaminan } \\
\text { Rahn) }\end{array}$ & $\checkmark$ & \\
\hline
\end{tabular}

\begin{tabular}{|l|l|c|c|}
\hline \multirow{2}{*}{ No } & \multicolumn{2}{|c|}{$\begin{array}{l}\text { Jual beli Emas } \\
\text { Secara tidak } \\
\text { tunai }\end{array}$} & \multicolumn{2}{|c|}{$\begin{array}{c}\text { Kesesuaian } \\
\text { Syariah }\end{array}$} \\
\cline { 3 - 4 } & \multicolumn{1}{|c|}{ Ya } & Tidak \\
\hline 4 & $\begin{array}{l}\text { Emas yang } \\
\text { dijadikan jaminan } \\
\text { tidak boleh } \\
\text { dijualbelikan atau } \\
\text { dijadikan objek } \\
\text { akad lain yang } \\
\text { menyebabkan } \\
\text { perpindahan } \\
\text { kepemilikan }\end{array}$ & $\checkmark$ & \\
\hline
\end{tabular}

Berdasarkan dalam point pertama mengenai emas tidak dijadikan alat tukar sudah sesuai ketentuan karena di pegadaian jalancagak emas hanya dijadikan objek jual beli tidak dijadikan sebagai alat tukar atau uang. Pada point kedua, harga jual tidak boleh bertambah selama jangka waktu perjanjian meskipun ada perpanjangan waktu setelah jatuh tempo, hal ini sudah sesuai dengan penerapan akad Murabahah di pegadaian jalancagak, karena di pegadaian jalancagak harga jual tetap sesuai akad awal tidak berubah meskipun ada perpanjangan waktu setelah jatuh tempo.

Point selanjutnya Emas yang dibeli dengan pembayaran tidak tunai boeh di jadikan jaminan, hal ini belaku juga di pegadaian Jalancagak karena emas belum boleh dimiliki atau dibawa pulang nasabah sebelum lunas angsuran atau setelah akad berakhir. Pada point ke empat Emas yang dijadikan jaminan tidak boleh di perjualbelikan atau dijadikan objek akad lain yang menyebabkan perpindahan kepemilikan hal ini sudah sesuai dalam penerapannya di Pegadaian jalancagak karena objek akad disimpan di tempat aman sampai akad berakhir. Dari ke empat poin diatas mengenai jual beli emas secara tidak tunai dalam penerapannya di pegadaian pada produk mulia sudah sesuai dengan syariat.

\section{Tabel 1.2}

Fatwa DSN-MUI no 111 tentang akad jual beli Murabahah

\begin{tabular}{|l|c|c|c|}
\hline \multirow{2}{*}{ No } & \multirow{2}{*}{$\begin{array}{c}\text { Ketentuan Objek } \\
\text { Murabahah }\end{array}$} & \multicolumn{2}{|c|}{$\begin{array}{c}\text { Kesesuaian } \\
\text { Syariah }\end{array}$} \\
\cline { 3 - 4 } & Ya & Tidak \\
\hline 1 & $\begin{array}{c}\text { Jual beli Murabahah } \\
\text { dilakukan atas barang } \\
\text { yang sudah dimiliki }\end{array}$ & & $\checkmark$ \\
\hline
\end{tabular}

R. Andriana Meirani | Penerapan Akad Murabahah pada ...... | 64 


\begin{tabular}{|c|c|c|c|}
\hline \multirow[t]{2}{*}{ No } & \multirow{2}{*}{$\begin{array}{c}\text { Ketentuan Objek } \\
\text { Murabahah }\end{array}$} & \multicolumn{2}{|c|}{$\begin{array}{c}\text { Kesesuaian } \\
\text { Syariah }\end{array}$} \\
\hline & & $\mathbf{Y a}$ & Tidak \\
\hline & $\begin{array}{l}\text { penjual pada saat } \\
\text { barang ditawarkan } \\
\text { kepada calon pembeli }\end{array}$ & & \\
\hline 2 & $\begin{array}{l}\text { Akad jual beli } \\
\text { Murabahah } \\
\text { dilakukan atas dasar } \\
\text { pesanan dari calon } \\
\text { pembeli }\end{array}$ & $\checkmark$ & \\
\hline 3 & $\begin{array}{l}\text { Al-bai bi al-taqsith } \\
\text { yaitu jual beli yang } \\
\text { pembayaran nya } \\
\text { dilakukan secara } \\
\text { angsur/bertahap }\end{array}$ & $\checkmark$ & \\
\hline 4 & $\begin{array}{lr}\text { Akad jual beli } \\
\text { Murabahah harus } \\
\text { dinyatakan secara } \\
\text { tegas dan jelas } & \text { serta } \\
\text { dipahami } & \text { dan } \\
\text { dimengerti } & \text { oleh } \\
\text { penjual dan pembeli }\end{array}$ & $\checkmark$ & \\
\hline 5 & $\begin{array}{lr}\text { Dalam perjanjian } \\
\text { Murabahah secara } \\
\text { tertulis dalam akta } \\
\text { perjanjian } \\
\text { terdapat informasi } \\
\text { mengenai } \\
\text { perolehan, } \\
\text { keuntungan dan harga } \\
\text { jual }\end{array}$ & $\checkmark$ & \\
\hline 6 & $\begin{array}{l}\text { Mutsman/mabi harus } \\
\text { wujud/jelas/pasti dan } \\
\text { dapat di serah- } \\
\text { terimakan pada saat } \\
\text { akad jual beli } \\
\text { Murabahah } \\
\text { dilakukan }\end{array}$ & & $\checkmark$ \\
\hline 7 & $\begin{array}{lr}\text { Ra's mal al- } \\
\text { Murabahah harus } \\
\text { diketahui } \\
\text { penjual dan pembeli }\end{array}$ & $\checkmark$ & \\
\hline 8 & $\begin{array}{l}\text { Harga dalam akad } \\
\begin{array}{l}\text { Murabahah harus } \\
\text { dinyatakan secara }\end{array} \\
\text { pasti pada saat akad }\end{array}$ & $\checkmark$ & \\
\hline
\end{tabular}

Poin pertama mengenai jual beli Murabahah dilakukan atas barang yang sudah dimiliki penjual pada saat barang ditawarkan kepada calon pembeli, maksudnya objek barang yang akan di jual belikan dalam hal ini Emas, harus sudah ada atau dimiliki pihak pegadaian. Sedangkan pada penerapannya pihak pegadaian tidak memunculkan objek yang dijadikan akad sehingga menyebabkan ketidak sesuaian dengan ketentuan syariah. Kedua, akad jual beli Murabahah dilakukan atas dasar pesanan dari calon pembeli. Maksudnya akad Murabahah di pegadaian akan terjadi apabila ada pesanan dari calon pembeli.

Ketiga, jual beli dilakukan secara angsur/bertahap maksudnya jual beli secara cicilan atau tidak tunai dalam hal ini sudah sesuai penerapannya di pegadaian jalancagak. Keempat, akad harus dinyatakan secara tegas dan jelas serta dipahami kedua belah pihak. Maksudnya ketika akad berlangsung kedua belah pihak harus sama sama mengerti dan paham dengan akad Murabahah yang berlangsung. Dalam hal ini pegadaian jalancagak membacakan secara jelas dan lugas ketentuan atau kontrak akad Murabahah ketika akad berlangsung dan memberikan kesempatan nasabah untuk bertanya apabila ada yang kurang dipahami oleh nasabah.

Kelima, dalam perjanjian Murabahah secara tertulis dalam akta perjanjian harus terdapat informasi mengenai harga perolehan, keuntungan dan harga jual. Maksudnya harga harus sudah disepakati jumlahnya oleh kedua belah pihak. Dalam hal ini sudah sesuai penerapannya di pegadaian Jalancagak. Keenam, Barang harus wujud, jelas, pasti dan dapat di serah-terimakan pada pada saat akad Murabahah berlangsung, maksudnya barang harus ada dimunculkan ketika akad Murabahah berlangsung sedangkan dalam penerapannya di Pegadaian Jalancagak objek akad (Emas) tidak dimunculkan hal itu tentu saja tidak sesuai dengan ketentuan syariat. Ketujuh, $R a$ 's mal al-Murabahah harus diketahui leh penjual dan pembeli yaitu harga pokok dari objek akad harus diketahui keduabelah pihak. Dalam hal ini pihak pegadaian memberitahukan harga pokok Emas yang akan dijadikan objek akad Murabahah dan tentu saja hal itu sudah sesuai dengan ketentuan atau syariat. Dari tabel diatas terdapat beberapa poin dalam ketentuan yang belum sesuai dengan syariat, diantaranya poin objek Murabahah nya yang seharusnya ada ketika akad Murabahah berlangsung sedangkan pada prakteknya di pegadaian barang pesanan tidak di sertakan dalam akad. 
Tabel 1.3

Fatwa DSN-MUI No 17 tentang Sanksi atas nasabah mampu yang menunda nunda pembayaran

\begin{tabular}{|c|c|c|c|}
\hline \multirow[t]{2}{*}{ No } & \multirow{2}{*}{$\begin{array}{c}\text { Ketentuan } \\
\text { Sanksi/Denda }\end{array}$} & \multicolumn{2}{|c|}{$\begin{array}{c}\text { Kesesuaian } \\
\text { Syariah }\end{array}$} \\
\hline & & Ya & Tidak \\
\hline 1 & $\begin{array}{l}\text { Sanksi dikenakan } \\
\text { untuk nasabah yang } \\
\text { mampu membayar } \\
\text { namun menunda } \\
\text { pembayaran } \\
\text { dengan sengaja }\end{array}$ & $\checkmark$ & \\
\hline 2 & $\begin{array}{l}\text { Nasabah yang tidak } \\
\text { mampu membayar } \\
\text { di sebabkan force } \\
\text { majeur tidak boleh } \\
\text { dikenakan sanksi }\end{array}$ & & $\checkmark$ \\
\hline 3 & $\begin{array}{l}\text { Sanksi bertujuan } \\
\text { agar nasabah lebih } \\
\text { disiplin dalam } \\
\text { melaksanakan } \\
\text { kewajibannya }\end{array}$ & $\checkmark$ & \\
\hline 4 & $\begin{array}{l}\text { Sanksi dapat } \\
\text { berupa denda } \\
\text { sejumlah uang yang } \\
\text { besarnya di } \\
\text { tentukan atas dasar } \\
\text { kesepakatan } \\
\text { bersama dan dibuat } \\
\text { saat akad di } \\
\text { tandatangani }\end{array}$ & $\checkmark$ & \\
\hline 5 & $\begin{array}{l}\text { Dana yang berasal } \\
\text { dari denda } \\
\text { diperuntukan } \\
\text { sebagai dana sosial }\end{array}$ & & $\checkmark$ \\
\hline
\end{tabular}

Berdasarkan penjelasan diatas pegadaian diperbolehkan memberikan denda apabila terjadi kelalaian pembayaran Murabahah dari nasabahnya. Namun, nasabah yang diperbolehkan untuk dikenakan denda adalah nasabah yang mampu tapi menunda pembayaran cicilan atau angsuran. Adapun dana yang didapatkan dari denda tersebut tidak boleh digunakan untuk operasional bank tetapi diperuntukan sebagai dana sosial. Acuan atas penerapan kebijakan ini diambil dari hadis Rasulullah SAW, "Menundanunda pembayaran utang yang dilakukan oleh orang mampu adalah suatu kezhaliman. Maka jika seseorang di antara kamu dialihkan hak penagihan utangnya (dihiwalahkan) kepada pihak yang mampu, terimalah." (HR. Bukhari, Muslim, Tirmidzi, Nasa'i, Abu Daud, Ibnu Majah, Ahmad, Malik, dan Darami).

Terdapat pada poin kedua seharusnya ada pengecualian bagi nasabah yang memang benar benar tidak mampu membayar, namun pihak pegadaian memberlakukan denda untuk semua nasabah yang telat atau tidak mampu membayar angsuran tanpa kecuali, sehingga hal litu tidak menyebabkan ketidak sesuaian dengan syariat.

Poin lima juga ada ketidak sesuaian, yang harusnya menurut syariat dana yang berasal dari denda di peruntukan bagi dana sosial, dalam hal ini Pegadaian menjadikannya sebagai pendapatan perusahaan.

Tabel 1.4

Fatwa DSN-MUI no25 dan 26 tentang Rahn dan Rahn Emas

\begin{tabular}{|c|c|c|c|}
\hline \multirow[t]{2}{*}{ No } & \multirow[t]{2}{*}{ Ketentuan Rahn } & \multicolumn{2}{|c|}{$\begin{array}{c}\text { Kesesuaian } \\
\text { Syariah }\end{array}$} \\
\hline & & Ya & Tidak \\
\hline 1 & $\begin{array}{l}\text { Murtahin mempunyai } \\
\text { hak untuk menahan } \\
\text { marhun sampai } \\
\text { semua hutang rahin } \\
\text { dilunasi }\end{array}$ & $\checkmark$ & \\
\hline 2 & $\begin{array}{lr}\text { Marhun } & \text { dan } \\
\text { manfaatnya } & \text { tetap } \\
\text { menjadi milik } & \text { Rahin }\end{array}$ & $\checkmark$ & \\
\hline 3 & $\begin{array}{lr}\text { Besarnya } & \text { biaya } \\
\text { pemeliharaan } & \text { dan } \\
\text { penyimpanan marhun } \\
\text { tidak } \\
\text { ditentukan } \\
\text { berdasarkan jumlah } \\
\text { pinjaman }\end{array}$ & $\checkmark$ & \\
\hline 4 & $\begin{array}{l}\text { Apabila jatuh tempo } \\
\text { murtahin harus } \\
\text { memperingatkan } \\
\text { rahin untuk segera } \\
\text { melunasi } \\
\text { "f` hutangnya }\end{array}$ & $\checkmark$ & \\
\hline 5 & $\begin{array}{l}\text { Apabila rahin tetap } \\
\text { tidak bisa melunasi } \\
\text { hutangnya maka } \\
\text { marhun } \\
\text { paksa/dieksekusi }\end{array}$ & $\checkmark$ & \\
\hline
\end{tabular}

R. Andriana Meirani | Penerapan Akad Murabahah pada ...... 66 


\begin{tabular}{|c|c|c|c|}
\hline \multirow[t]{2}{*}{ No } & \multirow[t]{2}{*}{ Ketentuan Rahn } & \multicolumn{2}{|c|}{$\begin{array}{c}\text { Kesesuaian } \\
\text { Syariah }\end{array}$} \\
\hline & & Ya & Tidak \\
\hline & $\begin{array}{l}\text { melalui lelang sesuai } \\
\text { syariah }\end{array}$ & & \\
\hline 6 & 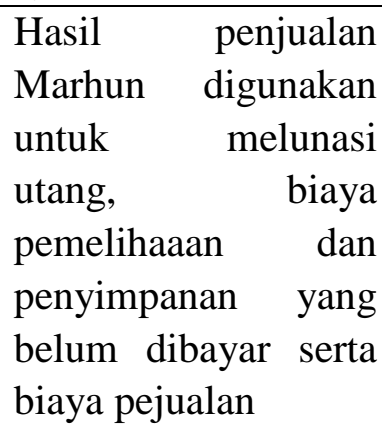 & $\checkmark$ & \\
\hline 7 & $\begin{array}{lr}\text { Kelebihan } & \text { hasil } \\
\text { penjualan } & \text { menjadi } \\
\text { milik Rahin } & \end{array}$ & $\checkmark$ & \\
\hline
\end{tabular}

Point pertama, murtahin Mempunyai hak untuk menahan marhun sampai semua hutang Rahin dilunasi, maksudnya sebelum cicilan atau angsuran nasabah lunas Emas ditahan atau disimpan pegadaian sampai nasabah selesai melunai kewajibannya. Kedua, Marhun dan manfaatnya tetap menjadi milik Rahin. Artinya pihak pegadaian hanya menyimpan Emas nasabah sampai nasabah selesai dengan kewajibannya dan manfaat emas tetap menjadi milik nasabah.

Ketiga, besarnya biaya penyimpanan marhun tidak boleh ditentukan berdasarkan jumlah pinjaman. Maksudnya biaya pemeliharaan boleh ditetapkan oleh pegadaian berdasar objek bendanya bukan berdasar jumlah pinjaman. Keempat, apabila jatuh tempo Murtahin harus memperingatkan rahin untuk segera melunasi hutangnya. Maksudnya adalah apabila telah jatuh tempo sementara nasabah belum melunasi hutangnya maka pihak Pegadaian berkewajiban untuk memperingatkan nasabah untuk segera melunasi hutangnya. Dalam hal ini pihak pegadaian sudah sesuai dalam penerapannya dengan cara selalu mengingatkan nasabahnya via telepon maupun surat untuk segera melunasinya.

Kelima, apabila Rahin tetap tidak bisa melunasi hutangnya maka maka marhun dijual paksa/di eksekusi melalui lelang sesuai syariat, maksudnya lelang atas Emas terpaksa dilakukan apabila nasabah tidak bisa melunasi kewajibannya. Dalam penerapannya di Pegadaian
Jalancagak sudah sesuai syariat. Keenam, hasil penjualan Marhun digunakan untuk melunasi utang, biaya pemeliharaan dan penyimpanan yang belum dibayar serta biaya penjualan. Artinya semua kewajiban Nasabah yang belum dipenuhi dibayarkan oleh hasil penjualan Emas nasabah yang di lelang.

Ketujuh, kelebihan hasil penjualan menjadi milik Rahin. Maksudnya apabila ada kelebihan dari hasil lelang setelah dikurangi kewajiban membayar pada pegadaian, maka sisa nya diberikan kepada nasabah. Dari beberapa poin fatwa DSN-MUI diatas mengenai ketentuan Gadai dan Gadai emas di pegadaian jalancagak dalam penerapannya sudah sesuai syariat.

\section{Dampak Produk MULIA Di Pegadaian Jalancagak Bagi Nasabah/ Konsumen Maupun Lembaga}

1. Sangat memudahkan bagi nasabah yang ingin memiliki produk tersebut. yang tadinya nasabah harus datang ke pusat kota yang berjarak $17 \mathrm{~km}$ dari desa jalancagak sekarang di pegadaian konvensional pun sudah melayani produk mulia yang berlandaskan syariah.

2. Pembelian emas/investasi emas melalui produk MULIA di pegadaian lebih mudah dibanding bank pembiayaan lain yang menyediakan pembiayaan cicil emas sejenis.

3. Pengajuan pembiayaan produk MULIA di pegadaian relatif yang mudah dan cepat.

Lembaga, dengan banyaknya permintaan pembelian produk MULIA secara tunai maupun cicilan maka pemasukan untuk perusahaan dari selisih margin semakin besar dan otomatis menguntungkan pihak lembaga Pegadaian.

\section{PENUTUP}

Berdasarkan analisis mengenai penerapan akad Murabahah pada produk mulia di Pegadaian Jalancagak baik dari segi ketentuan produk dan perspektif ekonomi syariah, dapat ditarik kesimpulan bahwa, produk Mulia pada Pegadaian salah satu akadnya menggunakan akad Murabahah, yaitu kesepakatan yang dibuat bersama antara pegadaian dan nasabah atas 


\section{EKSISBANK Vol. 4 No. 1 Juni 2020}

sejumlah pembelian Logam Mulia disertai euntungan dan biaya-biaya yang disepakati. Aplikasi akadnya dilakukan pada saat pertama nasabah mengajukan permohonan investasi Logam Mulia di Pegadaian. Kemudian, oleh pihak pertama (pegadaian) dan pihak kedua (nasabah) melakukan kesepakatan dan persetujuan untuk mengadakan Akad Murabahah Logam Mulia, dengan syarat dan ketentuan yang harus di sepakati kedua belah pihak sesuai pasal-pasal perjanjian (terdiri dari 12 pasal) yang tercantum pada dokumen mulia secara jelas.

Dari hasil pembahasan peneliti terdapat beberapa ketentuan dalam penerapan akad Murabahah produk MULIA di Pegadaian Jalancagak yang belum sesuai dengan ketentuan syariat, diantaranya; pertama mengenai Objek akad atau Marhun yang tidak dimunculkan atau tidak ada ketika akad berlangsung. Kedua, mengenai sanksi yang dibolehkan menurut syariat adalah berlaku untuk nasabah yang mampu tapi lalai atau menunda nunda pembayaran tapi tidak berlaku untuk nasabah yang benar-benar tidak mampu membayar, namun dalam penerapannya di pegadaian Jalancagak mengharuskan semua nasabah menerima sanksi atau membayar denda apabila tidak mampu membayar tanpa kecuali. Ketiga, dalam penerapan sanksi/denda mengenai dana yang dihasilkan dari denda di masukan sebagai pendapatan Perusahaan, yang secara ketentuan syariat seharusnya diperuntukan untuk dana sosial.

\section{DAFTAR PUSTAKA}

Afrida, Y. (2016). Analisis Pembiayaan Murabahah Di Perbankan Syariah. JEBI (Jurnal Ekonomi Dan Bisnis Islam), 1(2), 155-166. https://doi.org/10.15548/JEBI.V1I2.32

Antonio, M. S. (2001). Bank Syariah Dari Teori Ke Praktik. Gema Insani Press.

Arikunto, S. (2016). Manajemen Penelitian. Rineka Cipta.

RAHN EMAS, Pub. L. No. 26/DSNMUI/III/2002 (2002).

RAHN, Pub. L. No. 25/DSN-MUI/III/2002 (2002).

Enang, S. (2010). Al-Qur'an dan Terjemah. PT
Madina Raihan Makmur.

Harpen, I. (2015). Kajian Akad Pembiayaan Logam Mulia Untuk Masyarakat Pada Pegadaian Syariah. MENARA, 13(1), 3960. http://ejournal.uin-suska.ac.id/index.php/Menara/article/view/841

Ismail, M. (2015). Pembiayaan Murabahah dalam Perspektif Islam. Syaikhuna: Jurnal Pendidikan Dan Pranata Islam, 6(2), 150 $164 . \quad$ http://ejournal.kopertais4.or.id/madura/index.php/syaikhuna/article /view/1033

Lubis, S. K. (2000). Hukum Ekonomi Islam. Sinar Grafika.

Mardani. (2015). Fiqh Ekonomi Syariah; Fiqh Muamalah (1st ed.). Kencana.

Maruta, H. (2016). Akad Mudharabah, Musyarakah, Dan Murabahah Serta Aplikasinya Dalam Masyarakat | IQTISHADUNA: Jurnal Ilmiah Ekonomi Kita.

http://ejournal.stiesyariahbengkalis.ac.id/i ndex.php/iqtishaduna/article/view/81

Rahayu, Y. S. (2019). Akad Murabahah pada Produk MULIA di Pegadaian Jalancagak. Pegadaian Jalancagak Subang.

Sri, N. (2009). Akuntansi Syariah di Indonesia. Salemba Empat.

Suhendi, H. (2010). Fiqh Muamalah. Raja Grafindo Persada.

Tanuwidjaja, W. (2009). Cerdas Investasi Emas. Medpress.

Taufik Diya, dan, Program Magister Manajemen, D., Program Magister Manajemen, A., \& Manajemen Pemasaran, K. (2012). Peran Faktor Psikologis Terhadap Keputusan Investasi Produk Mulia Pada Pt. Pegadaian (Persero) Di Kota Jambi (The Role of Psychological Factors on Investment Decision of MULIA Product at PT. Pegadaian (Persero) in Jambi City). DIGEST MARKETING, 1(3), 210-221. https://online-journal.unja.ac.id/digest/article/view/1560 